\title{
Wielka Kołomyja Wokół ludyczności w wybranych powieściach Edmunda Niziurskiego
}

\begin{abstract}
The author of the paper explores two dichotomous phenomena - boredom and entertainment - in Polish prose for children from the period of PRL, basing on the adventure novels written by Edmund Niziurski in the 1960s: Awanturza w Niekłaju (1962) and Siódme wtajemniczenie (1969). Both notions are discussed from the perspective of ethnography, anthropology, and the history of childhood. Referring to Roger Caillois's concepts of play and games, the researcher analyses the images of transformation of entertainment behaviours as presented by young characters from Niziurski's novels, and links between the text and social and political reality in Poland of the 1960s. Her findings indicate that, in his writing of this period, Niziurski both withdrew from socrealistic poetics and abandoned the ideological, persuasive function of entertainment for the sake of uninhibited, spontaneous children's games and play.
\end{abstract}

Key word s: Edmund Niziurski, entertainment, children's folklore, boredom

\section{Wprowadzenie}

Zabawie oddajemy się wtedy, gdy „znudzenie kładzie kres temu, co zapoczątkowała ochota”, wyjaśnia Paul Valéry (za: Caillois, 1973, s. 301). Przyjmując myśl francuskiego poety, Roger Caillois dodaje, że główną zasadą zabawy jest chęć wyłączenia się z powszedniego życia, chęć rozerwania się i zapomnienia o troskach (Caillois, 1973, s. 301-302). Autor klasycznej książki Gry i ludzie określa ją jako aktywność dobrowolną - wesołą oraz bezinteresowną, z elementem niepewności, dającą uczestnikom odprężenie i swobodę, choć zamkniętą w ramach określonych konwencji. Zabawa wytrąca ze stanu bierności, zniechęcenia, zakłada konieczność wykazania się działaniem, energią, także kreatywnością. Znudzenie w kontekście dzieciństwa wartościowane bywa negatywnie, bo - w odróżnieniu od postawy ludycznej - wyklucza pełną radość, kojarzy się z melancholią, ze złym samopoczuciem, nawet z cierpieniem. Oznacza deficyt lub wprost 
przeciwnie - nadmiar bodźców i wrażeń, co amerykański psycholog Richard Winter nazywa „chorobą naszych czasów” (Winter, 2012). Odczucie znużenia kłóci się ponadto z Jerzego Cieślikowskiego wizją „wielkiej zabawy”, czyli tego wszystkiego, „co dzieci wzięły od dorosłych, co dla nich dorośli stworzyli, co same wymyśliły i wreszcie co dorośli dla nich napisali najlepszego" (Cieślikowski, 1985, s. 6).

Sposoby radzenia sobie z nudą układają się w niekończący się ciąg gier i zabaw, które dały początek wielu trwałym formom kulturowej ekspresji, o czym traktuje pionierska praca wrocławskiego badacza, by przywołać choćby słynną ciuciubabkę (ślepą babkę), popularną niemal w całej Europie od czasów starożytnej Grecji i Rzymu. Paradoksalnie właśnie sytuacja chwilowej stagnacji, chwilowego „nicnierobienia” staje się decydującym czynnikiem fabułotwórczym, który uruchamia, cytując Ryszarda Waksmunda, „przygody ludyczne” w wielu reprezentacjach prozy dla nastolatków XX i XXI wieku (Waksmund, 2000, s. 370). Zagadnienie, któremu zamierzam przyjrzeć się w niniejszym tekście, lokuje się na pograniczu etnografii i antropologii dzieciństwa, dotyczy zaś dwóch biegunowo układających się zjawisk - nudy i zabawy jako przejawów ścierania się tradycyjnego folkloru dziecięcego $\mathrm{z}$,ideowo-wychowawczą" rozrywką (prymitywną, nieautentyczną i totalną), jaką serwowano dzieciom i młodzieży w dobie PRL-u. Przyglądam się motywom znużenia, apatii oraz entuzjastycznemu aktywizmowi w dwóch klasycznych powieściach przygodowych Edmunda Niziurskiego z lat sześćdziesiątych ubiegłego wieku: Awanturze w Niekłaju (1962) oraz Siódmemu wtajemniczeniu (1969). Obydwie znamionują - co należy podkreślić - proces odchodzenia popularnego pisarza od poetyki socrealistycznej (Nowak, Ryszkiewicz, 2006, s. 180-185), a także jego uwolnienie się od obowiązkowej dla twórców literatury czwartej w latach pięćdziesiątych XX wieku tendencyjności oraz konkluzywności.

\section{Pomysły na nudę}

Protagoniści utworów cierpią na nadmiar wolnego czasu lub brakuje im pomysłu na ciekawe spędzenie wakacji. Z niechęcią myślą o następnym dniu podobnym do poprzedniego. Są sfrustrowani koniecznością codziennego wypełniania tych samych obowiązków, przymusem szkolnym, nużącymi lekcjami i przynudzającymi nauczycielami. Bohaterowie pokroju Karlika Rudnioka z Ksieggi urwisów buntują się przeciwko marazmowi prowincji, gdzie - jak wykrzykuje w rozpaczy — „jest tak nudno!”. Wyczekuje on możliwości spełnienia ukrytych marzeń o byciu kimś niezwykłym, najlepiej prawdziwym śledczym, detektywem albo wręcz łowcą przygód. Sens takiego obrazu nudy trafnie oddaje, na wpół ironiczna, wypowiedź narratora - młodego dziennikarza szkolnej gazetki Tomka Okista, otwierająca Naprzód, Wspaniali! (1971) Edmunda Niziurskiego: 
Od września notuję w tym brulionie pewne zdarzenia z naszego szkolnego życia. Oczywiście nie będą one figurować w prawdziwej książce, którą wkrótce napiszę. Nie są na tyle ważne ani śmieszne, ani straszne. Notuję je po prostu tak sobie, dla treningu, żeby nabrać pisarskiej formy i wyrobić sobie styl, a naprawdę to czekam... Czekam, a raczej czyham, bo to jest niecierpliwe, czujne i pełne napięcia czekanie, żeby coś okropnego zdarzyło się w naszym poczciwym miasteczku, w tych nudnych Odrzywołach. Oczywiście jest to uzależnione przede wszystkim od pojawienia się u nas odpowiedniego opryszka, opryszka przez bardzo duże O. Tak, najpierw musi pojawić się On, Wielki Zły, z którym można się będzie zmierzyć!... Nie wiem jeszcze dokładnie, kim on będzie. Może groźnym zbrodniarzem, może szefem niebezpiecznej bandy, może szpiegiem?. . Jedno jest pewne, musi być bardzo zły i sprytny.

Pewne poszlaki świadczą, że już się sposobi. Podejrzewamy, że ukrywa się w starym browarze i montuje tam swoją szajkę. Ten opuszczony browar przy ślepej uliczce nad rzeką na pewno kryje ważne tajemnice.

Niziurski, 1977, s. 5

Cała tzw. odrzywolska trylogia, na którą, poza wymienioną - przypomnę - składają się jeszcze Adelo, zrozum mnie! (1977) i Awantury kosmiczne (1978), podobnie jak wcześniejsze powieści Niziurskiego, przynosi interesujące świadectwa sposobów wypełniania „emocjonalnej pustki” w życiu nastoletnich chłopców, żyjących na różnych etapach Polski Ludowej, by wspomnieć Marka Piegusa (Niewiarygodne przygody Marka Piegusa), Gustawa Cykorza (Siódme wtajemniczenie) czy Tomka Żabnego (Szkolny lud, Okulla i ja). Z melancholijnych nastrojów uwalnia ich wizja ekscytującej przygody. Obszerny rejestr jej rodzajów sporządziła Gertruda Skotnicka, wyodrębniając dwie zasadnicze struktury fabuł przygodowych w prozie autora Lizusa (Skotnicka, 1996, s. 55-70). Pierwsza opiera się na konwencjach ludycznych, gdyż komizmem autor dezawuuje nawet najbardziej „mrożące krew w żyłach” momenty (np. Przygody Bąbla i Syfona). Drugą badaczka określiła mianem "fabuł tragicznych” ze względu na towarzyszącą protagonistom do końca iluzję rzeczywistego niebezpieczeństwa (Skotnicka, 1996, s. 57-58). Autora „odrzywolskiej trylogii” cechuje duża inwencja w łączeniu intrygi kryminalno-detektywistycznej ze scenariuszami tradycyjnych zabaw dziecięcych. Preferuje on motywy agonistyczne (podchody, rywalizację między szkołami, bandami, paczkami; zawody sportowe, mecze etc.) oraz naśladowcze (np. inscenizacje bitew), ale też chętnie tworzy kombinacje różnych odmian, które wyodrębnił Caillois.

Warto dodać, że w tle „awantur” toczy się ważniejszy bój nie tyle z nudą, ile o prawo do samodzielnego decydowania o sposobach spędzania wolnego czasu, o zainteresowaniach, nienarzuconych ani przez szkołę, ani żadną inną instytucję. Sympatyczne „łobuziaki” w typie Ciamciary ze Sposobu na Alcybiadesa zakładają więc własne bandy, jakby na przekór władzom szkolnym, które starają się ukrócić wszelkie uczniowskie próby samoorganizowania się (Kosiński, 2006). 


\section{Być w tajnym związku}

„Nie masz kondycji [...] i w ogóle maminsynków nie przyjmujemy”, słyszy Światek Dauer werdykt Związku Piratów (Tubylców), gdy chce wstąpić w ich szeregi. Chłopak próbuje nawet przekupić dowództwo lodami, twierdząc, że zadowoli się choćby najniższym stopniem kaprala. Mimo to Tubylcy pozostają nieugięci. Jako potencjalny szpieg Piratów, zostaje również odrzucony przez drugą z niekłajskich band, czyli Kolonistów. W akcie „desperacji” Adenauer, bo takie przezwisko nadano mu w szkole, postanawia więc zwrócić się do dziewczęcego Związku Zielonych Jaszczurek, choć jest świadomy, że w ten sposób sięga „dna upadku i hańby”. Niestety, i tutaj spotyka go odmowa. Światek, jeden z bohaterów Awantury w Niekłaju, z zazdrością przygląda się, gotów zgodzić się na największe upokorzenie, byle dołączyć do jednej z grup poszukiwaczy przygód.

Ten z pozoru mało znaczący epizod, mimo że autor nadał mu charakter satyryczny, akcentuje bardzo poważny problem z punktu widzenia młodziutkiego bohatera prozy przygodowej, mianowicie tęsknotę za „niezwykłym dzianiem się", chęć zapełnienia pustki w życiu, poszukiwanie ekscytacji, rozrywki, szansy na zerwanie z monotonią (Baluch, 1987, s. 32). Warto dodać, że drugoplanowa postać $\mathrm{z}$ omawianego utworu doświadcza nudy w iście romantycznym stylu (Kotliński, 1999). Raz dopada go depresyjny nastrój, innym razem ostentacyjnie gwiżdże na wszystkich chłopców z Niekłaja, gdzie przeniósł się wraz z ojcem cenionym inżynierem w lokalnych Zakładach Metalowych. Brak czasu dla syna ojciec próbuje zrekompensować, zasypując go prezentami. Światek ma wszystko, o czym mogą jedynie pomarzyć jego rówieśnicy: latające modele samolotu, lornetkę, pistolety zabawki, rower. Wydaje się, że chłopiec powinien być szczęśliwy, tymczasem jest wręcz odwrotnie. Każdy z cennych prezentów chłopiec oddałby bez wahania, byle tylko mógł uczestniczyć w zabawach jednego z niekłajskich plemion. Kolejne nieudane próby zbliżenia do tutejszej społeczności pogłębiają jego rozgoryczenie, wywołują gniew, co prowadzi do dramatycznej decyzji o zostawieniu ojca i ucieczce "gdzieś bardzo daleko” od tego miasta.

Analizowany utwór przedstawia ciekawe z perspektywy poetyki historycznej świadectwo uwalniania się Niziurskiego od schematu perswazyjnego, a dokładniej: od propagandowej funkcji powieści (Białek, 1996, s. 19). Sensacyjną fabułę Awantury w Niekłaju uruchamia pytanie: Kto jest szpiegiem? Kto usiłuje wykraść pilnie strzeżony wynalazek - sztabkę stopu łożyskowego do „silnika beztłokowego"?. Oprócz głównego bohatera - Michała i innych chłopców ze związku Piratów, którzy wcielają się w rolę detektywów, mamy też wodza konkurencyjnego plemienia Kolonistów - Andrzeja Kszyka. Dorosłych zaś reprezentują: ojciec Michała - technik z Zakładów Metalowych w Niekłaju, inżynier Ankwicz,

\footnotetext{
${ }^{1}$ Niziurski, 1975, s. 39.
} 
wreszcie na poły komiczna postać harcmistrza Gwidona Otrębusa. Chociaż młodzi Niziurskiego przejmują schematy myślowe dorosłych, to socjalistyczną wymowę niweczy nagromadzenie w powieści absurdalno-groteskowych sytuacji, do czego wrócę w dalszej części rozważań.

Gustaw Cykorz, protagonista Siódmego wtajemniczenia, postanawia wstąpić do "męskiego" bractwa z zupełnie innych powodów, bynajmniej nie dobrowolnie. Podobnie jak Adenauer, wciąż musi zmieniać szkołę, przenosząc się wraz z kolejnymi „delegacjami” ojca. Tym razem trafia do Gnypowic Wielkich, kolejnego fikcyjnego punktu na literackiej mapie Niziurskiego. Szczegóły topografii, górniczy krajobraz, poniemiecka historia sugerują miasteczko na Górnym Śląsku. Ciągłe przeprowadzki z miejsca na miejsce sprawiają, że Cykorz boleśnie doświadcza bycia „wiecznym Nowym” („fuksem”). Zdarzyło się, że nawet dwa razy w roku szkolnym przechodził różnorakie „zabiegi higieniczne”, które fundowały mu klasowe bractwa, zanim go zaakceptowały, lecz wysiłki, by cierpliwie znosić owo „docieranie, ujeżdżanie, szlifowanie”, i tak szły na marne, gdyż wtedy znowu przenosił się gdzie indziej (Niziurski, 1969, s. 19)².

Gnypowicka placówka okazuje się „najtrudniejsza” ze wszystkich. Rządzą w niej dwie zwalczające się bandy: Matusów i Blokerów. Cykorz ma wyjątkowego pecha, bo trafia w sam środek regularnej wojny między nimi. Taktyka bycia „wolnym strzelcem”, unikania zarówno jednych, jak i drugich, przynosi mizerne efekty:

Boisko zajęte było przez chłopaków z siódmej A. Należeli oni wszyscy do bractwa Matusów, a wolałem omijać ich z daleka, bo ile razy wlazłem im pod rękę, zawsze dawali mi wycisk. Rzecz w tym, że ja chodziłem do szóstej B i uważali mnie za Blokera, a między Matusami i Blokerami panował stan nieustannej wojny. Takie tu panowały stosunki w tych przeklętych Gnypowicach Wielkich.

Przetrwanie $\mathrm{w}$ takich warunkach wymaga od Cykorza akcesu do któregoś $\mathrm{z}$ bractw, co też postanawia uczynić, licząc, że będzie bezpieczny przynajmniej od jednej strony. Niezależnie od motywacji Światek Dauer i Gustaw Cykorz chcieliby nawiązać więź z kolegami, doświadczyć przyjaźni, braterstwa, razem przeżywać wielką przygodę, najlepiej w konspiracyjnie działającej wspólnocie, która w powieściach młodzieżowych przybiera kształt oraz nazwę bractwa, związku, bandy, gangu, klubu, stowarzyszenia, „młodzieżowego biura”.

Zauważmy różnice semantyczne w wymienionych terminach. Definicja słownikowa określa „bractwo” jako „grono współtowarzyszy” albo „świeckie zrzeszenie wiernych mających na celu jakiś szczególny kult religijny"3. Można do-

${ }^{2}$ Dalej cytuję według tego wydania. Cyfry w nawiasach oznaczają numery stron.

${ }^{3}$ Wszystkie przytaczane definicje podaję za internetowym Słownikiem języka polskiego PWN. [Dokument elektroniczny]. http://sjp.pwn.pl/sjp/1.;2445871 [data dostępu: 10.11.2018]. 
dać za Eliadem, że w pierwszym przypadku chodzi o męskie grono (Eliade, 1997, s. 17). Spośród podanych terminów jedynie „banda” („grupa ludzi dokonujących wspólnie napadów i rabunków”) oraz „gang” („zorganizowana grupa przestępców") mają znaczenie negatywne. Pozostałe mówią o organizacji skupiającej ludzi z określonego środowiska i o określonym wieku, których łączą wspólne zainteresowania oraz cele.

W przypadku nastolatków akces do wspólnoty sygnalizuje dorastanie, bo oznacza „wyjście z domu”, uwolnienie się spod kurateli rodziców. Bycie w „bratnim związku" sprzyja swobodzie myślenia i działania. Wymaga od młodych ludzi przestrzegania zasad lojalności, wierności, bezkompromisowości, czasami bezwarunkowego opowiedzenia się po właściwej stronie. By wstąpić do organizacji, starający musi się natrudzić. Bohaterowie Niziurskiego poznają sekrety grupy pod warunkiem przejścia trudnego procesu wtajemniczenia.

\section{Siódme wtajemniczenie}

Etnolodzy wyróżniają trzy kategorie inicjacji. Pierwsza obowiązuje wszystkich członków społeczności i dokonuje się w efekcie przejścia z dzieciństwa lub młodości do dojrzałości. Dla „wybranych” (np. zarezerwowanych dla jednej płci) przeznaczona jest druga kategoria, która obejmuje obrzędy wejścia do stowarzyszenia tajemnego. Także jedynie wybrańcy - szamani, kapłani, znachorzy dostępują powołania mistycznego, czyli trzeciej kategorii inicjacji (Eliade, 1997, s. $16-17)$.

Rozważamy tu postać adepta aspirującego do wejścia w zamkniętą grupę szkolną bądź podwórkową. Poprzedźmy dalsze dociekania, pytając, w jaki sposób twórcy literatury młodzieżowej okresu PRL-u spożytkowali ową tradycję „stowarzyszeń tajemnych"? W jaki sposób wykorzystali motywikę związaną z tego typu aktywnością, czyli zwyczaje, gesty i formuły, przysięgę, symbole, miejsca zebrań - piwnice, ruiny, opuszczone domy?

Tworzenie nieformalnych stowarzyszeń w realiach „małej stabilizacji” było niemile widziane przez peerelowskie władze oświatowe, choć w przeciwieństwie do okresu stalinowskiego „przymykano na nie oko”. Według ustaleń historyka Krzysztofa Kosińskiego, starano się nadal zaanektować czas wolny młodzieży, kontrolując jej poczynania poza budynkiem szkoły. W początkach lat pięćdziesiątych maksymalnie wydłużano pobyt dzieci w placówce, organizując zajęcia pozalekcyjne, czyny społeczne, różne zbiórki oraz zebrania. „Pozaszkolnym oddziaływaniem wychowawczym" objęte były również wakacje, preferowano bowiem zorganizowany wypoczynek. Próbowano ograniczyć rozrywkę i rekreację do przestrzeni szkoły, świetlicy, domu harcerza, domu kultury. Tego typu działania dawały jednak połowiczne efekty (Kosiński, 2006, s. 288-289). 
Po roku 1956 sytuacja zmieniła się o tyle, że poszerzyła się sfera życia prywatnego starszej młodzieży o masowe formy rozrywki (kino, radio, telewizję, koncerty i festiwale muzyki), modę kawiarnianą oraz prywatki. Dzieciom dano również większą swobodę w organizacji „podwórkowych” zabaw i rekreacji, co nie zmienia faktu, że ich forma oraz ilość zależały od środowiska, w którym wychowywały się nastolatki. Z pewnością na wsiach problemem był raczej nadmiar obowiązków aniżeli znudzenie. Przez cały okres PRL-u niedorośli niechętnie odnosili się do rozrywek oferowanych im w placówkach szkolno-wychowawczych. Starali się, konstatuje Kosiński,

uniknąć wpisania w schemat: szkoła, organizacja młodzieżowa, dom kultury [...]. W rzeczywistości młodzież prowadziła z rządzącymi swoistą grę o wolny czas. Stawką w niej była swoboda i niezależność od instytucji oficjalnych. Młodzież zdobywała w tej grze przewagę.

Kosiński, 2006, s. 289

Podobny punkt widzenia znajdziemy w antropologicznym szkicu Andrzeja Kotlińskiego na temat nudy nastoletniego bohatera prozy dla dzieci i młodzieży w okresie PRL-u. Interpretację idei tworzenia nieformalnych związków rozpoczyna od specyfiki realiów „epoki Gomułki”, kiedy toczy się akcja wszystkich wymienionych dotychczas utworów (Kotliński, 1999). Badacz zauważył, że remedium na nudę dławiącą młodzież w czasie wolnym, szczególnie na prowincji, miały być owe klubokawiarnie, oferujące zajęcia świetlicowe, ping-pong, warcaby, kółka modelarskie, sekcje sportowe, szczególnie zaś kontrolowane przez państwo drużyny harcerskie. Pod okiem drużynowego młodzież mogła brać udział w plenerowych imprezach bądź zabawach ruchowych (Kotliński, 1999, s. 195). Notabene jedną z takich imprez, mianowicie rekonstrukcję bitwy pod Grunwaldem, przed świętem 22 lipca wykpił Niziurski w Awanturze w Niekłaju.

Młodziutkim pasjonatom przygody nie wystarcza już rozrywka pod czujnym okiem harcmistrza ani satysfakcja z budowy aparatu do porozumiewania się z kosmitami. Wybierają zatem „arcyromantyczne rozwiązanie: zakładają tajne związki zwane »bandami« [...], »gangami« czy najczęściej »sprzysiężeniami«, oparte na hierarchicznej, podbudowanej inicjacyjnym rytuałem strukturze, których celem jest prowadzenie walki na śmierć i życie z zabójczą jałowością i monotonią dnia codziennego" (Kotliński, 1999, s. 195). Romantyczną proweniencję zdradza wspominany Związek Piratów z Awantury... (Janion, Żmigrodzka, 2001, s. 393-435). Bractwo tworzą chłopcy, tubylcy - uczniowie tutejszej podstawówki. Łączą ich wspólne zainteresowania, miłość do „pirackich opowieści” Bosmana Rei, która przekłada się na marynistyczne scenariusze zabaw, rekwizyty (chusty z insygniami pirackimi, luneta, persykop), rytualne gesty, wreszcie hierarchię oficerską (na czele związku stoi admirał Zenek). Piraci kierują się zasadami koleżeństwa, przyjaźni i lojalności. Mają swoją kwaterę w domu Bos- 
mana (fregata „Resplandor”), ulubione miejsce zabaw - zdziczały park zwany Ogrodem, kryjący wiele tajemnic. Krótko mówiąc, idealne miejsce do poszukiwania skarbów. Związek przypomina zbiorowość chłopców w rodzaju republiki dziecięcej. Jedynym celem Piratów jest przeżycie prawdziwej przygody:

Ile razy po trudach przeprawy Piraci wkraczali do Ogrodu, od razu ogarniało ich znane, przyjemne uczucie swobody i odprężenia. Nigdzie nie czuli się tak dobrze jak w Ogrodzie. Tu była prawdziwa wolność. Tym przyjemniejsza, że trudna do zdobycia.

Dzisiaj to wszystko czuli jeszcze mocniej. Spodziewana przygoda nadała wszystkiemu pełny smak. Ten ranek w Ogrodzie był wyjątkowo świeży, powietrze rześkie, a zieleń soczysta. Umyślnie przechodzili przez największe gąszcza, bo wtedy zimna rosa z pajęczyn i liści padała im na rozgrzane policzki i to było bardzo przyjemne, choć żaden szanujący się Pirat nie przyznałby się do tego. Gdyby nie stanowczy zakaz Zenona, krzyczeliby, śpiewaliby z radości. Ale względy bezpieczeństwa obowiązywały.

Energia młodocianych poszukiwaczy przygód Siódmego wtajemniczenia Niziurskiego wkrótce zostanie przekierowana na inny cel - „Wielką Grę”, przywołując słowa Kotlińskiego, w której przeciwnikiem jest groźny szpieg (Kotliński, 1999, s. 196). Piraci z Niekłaja muszą „dopasować się” do współczesnych ról - amatorów detektywów, „bojowników słusznej sprawy”, natomiast głód dalekomorskich wypraw czy poszukiwania ukrytych skarbów mogą zaspokajać jedynie dzięki symbolicznym zabawom.

Tej naiwności, chłopięcości brakuje Kolonistom. Konspiracja, wolność od nakazów i zakazów dorosłych, braterska więź, wiara w zwycięstwo, honor, rytuał inicjacyjny, rytuał zebrań, symboliczne rekwizyty, wspólna lektura Robinsona Crusoe, odludne miejsce zabaw - taka architektura związku nie mieściła się w kategoriach drużyny socjalistycznej. Różnicę światopoglądową konkurujących drużyn najlepiej oddaje odmienne podejście do Ogrodu. Koloniści chcą uporządkować i zagospodarować teren, wybudować tam boisko sportowe. Dla drużyny Piratów oraz dziewczęcego Związku Zielonej Jaszczurki to miejsce jest atrakcyjne właśnie ze względu na swoją dzikość, tajemniczość, „puszczańską ciszę", usytuowanie, ruiny przedwojennego pałacu. Dążą więc do zachowania Ogrodu w niezmienionym kształcie dla siebie i mieszkających tam zwierząt.

Nawet wizerunkowo Koloniści odbiegają od bractwa miłośników bezinteresownej przygody. Jednakowo ubrani: w białych cyklistówkach, koszulkach gimnastycznych i spodenkach harcerskich, spędzają czas tylko pożytecznie, wspólnie uprawiają gimnastykę, „ćwiczenia astronautyczne”, wystrzeliwują rakiety w kosmos.

Parodystyczno-satyryczne ujęcie młodzieżowego związku widać w Siódmym wtajemniczeniu. To rzut monetą decyduje, do którego bractwa Matusów przystę- 
puje adept Gustaw (czytelna aluzja do słynnego bohatera romantycznego). O odczuciu spontanicznego braterstwa nie może być mowy. Również tajemniczość i konspiracja, dwie główne zasady spiskowej taktyki, w powieści Niziurskiego znajdują wyraz $\mathrm{w}$ ironicznym poczuciu humoru pisarza oraz komicznym postrzeganiu świata. Dobrze odzwierciedla to dialog, opisujący sekretną lokalizację kwatery Matusów:

- Czy długo tak będziecie mnie tryndać? - zapytałem — wleczecie się już chyba godzinę.

- Pół godziny - zasapał Kwiczoł.

- Mówiliście, że to niedaleko.

— Niedaleko, ale my kołujemy — powiedział Czarny Piter.

- Kołujecie?

- Kołowanie jest konieczne - jęknął Piter.

- Co ty bredzisz...

- Ze względów bezpieczeństwa droga do naszej kwatery jest niezwykle skomplikowana.

- Żeby wróg nie mógł przeniknąć - dodał Kwiczoł, ocierając pot z czoła.

- Nawet nasi członkowie nie znają drogi...

- Żartujesz chyba - zdumiałem się - więc kto zna?

- Tylko głębiej wtajemniczeni.

Pisarz skonstruował bodaj najciekawszy w polskiej prozie młodzieżowej tamtego okresu obraz tajnego stowarzyszenia, znakomicie przetwarzając stereotyp „męskiej” bandy i żonglując nim. Zabawa literacka obejmuje różne elementy obrazu tajemniczego związku, począwszy od opornego nowicjusza przez osobliwe gesty i ceremoniały, takie jak picie mlekozy, nacieranie ciała pokrzywami, biurokrację, heroikomiczne wyprawy do twierdzy Blokerów, na „tajemnej księdze” bractwa skończywszy (Baluch, 1992, s. 58-66)

Z dociekań Andrzeja Niewczasa wynika, że podstawową zasadą organizującą fabułę $\mathrm{w}$ analizowanych powieściach jest opozycyjność, zarówno w wymiarze osobowym: dorośli - dzieci, chłopcy - dziewczęta, wódz — podkomendni; przestrzennym: Niekłaj - Ogród Szwajsa, jak i czasowym: rok szkolny — wakacje (Niewczas, 1978, s. 148-158). Dychotomia między związkami warunkuje dynamiczny przebieg zdarzeń, uzasadnia wszystkie napięcia oraz konflikty. Tak więc Matusi, podobnie jak Blokerzy, demonstrują swoją siłę, organizując różne sztubackie draki i awantury. Pole „bitew” między nim często przenosi się

4 Tę „cenną” książkę znalazł Pleksik, jeden z Matusów, w skupie makulatury. Ponieważ była pozbawiona okładki i pierwszej strony, znalazca sam nadał jej tytuł: Niezwykłe przygody Anatola Stukniętego na początku. Ten kolejny intertekstualny trop w Siódmym wtajemniczeniu dowcipnie przeinacza ideę Księgi jako poszukiwania prawdy (anagnorisis). 
z twierdzy Persil do łaźni szkolnej lub na boisko. Quasi-militarne zabawy między Kolonistami i Piratami czy Wielką Kołomyję Elementarną w Siódmym wtajemniczeniu możemy uznać za literacki zapis jednej z form rytualnego ścierania się konkurencyjnych drużyn, które trzymają się określonego kodeksu. O zwycięstwie decydują szybkość, wytrwałość, siła i pamięć, zręczność, inteligencja, pomysłowość etc. (Caillois, 1973, s. 309).

\section{Być jak Andrzej Kszyk}

Wdzięcznym obiektem obserwacji są wodzowie band czy związków. W kreacji Ernesta Niziurski uciekł się do komicznej przesady, podkreślając na poły legendarną omnipotencję herszta Matusów. Mimo długiej nieobecności w szkole z powodu złamanej nogi jego imię wciąż jest na ustach wszystkich podkomendnych. Wygłaszane przez nich zdania typu: „Z Ernestem nie ma żartów”, „Ernest postanowił, że musisz do nas należeć”, „Czy mam zameldować Ernestowi, że znów się buntujesz?” układają się w konterfekt twardego, charyzmatycznego dowódcy i nieomylnego stratega. O skuteczności takiej propagandy świadczy reakcja głównego bohatera Siódmego wtajemniczenia podczas pierwszego spotkania $\mathrm{z}$ wodzem:

Zobaczyłem go po raz pierwszy. Od marca nie chodził do budy. Podobno złamał nogę w jakichś podejrzanych okolicznościach i przez dwa miesiące był w gipsie. Dopiero niedawno zaczął poruszać się o własnych siłach. Patrzyłem na niego zaskoczony. Zupełnie inaczej wyobrażałem sobie sławnego wodza Matusów. Nie wiem, dlaczego zdawało mi się, że musi wyglądać jak atleta i być wyższy od zwykłych Matusów co najmniej o głowę. Oczywista bzdura. Wzrost jeszcze o niczym nie świadczy. Przypomniałem sobie, że wielcy wodzowie byli przeważnie małego wzrostu, no choćby taki Napoleon. I zaraz pomyślałem, że jeśli Ernestowi mimo tak mizernych warunków fizycznych udało się zostać wodzem, musi mieć widać jakieś nadzwyczajne zalety umysłu i charakteru. I tym większy zdjął mnie wstyd, że zastał mnie w tak żałosnej pozycji.

Ten niemalże mityczny portret dyktatora przekształca się w karykaturę, gdy nowo przyjęty do bandy widzi absurdalne eksperymenty chemiczne, jakie przeprowadza Ernest $\mathrm{z}$ kozim mlekiem, albo kiedy dowiaduje się, że wódz koresponduje z ukochaną Małgosią za pośrednictwem gołębi pocztowych.

Herszt Kolonistów Andrzej Kszyk z Awantury w Niekłaju, jak sam mówi, zdobył władzę dzięki ojcu, ponieważ ten „tak długo doskwierał mu swą troskliwością, uwagami, tak wmawiał Andrzejowi, że jest delikatny, nieodporny i słaby, aż Andrzej zaczął uciekać z domu, ćwiczyć ciało i próbować swoich sił w za- 
bawach z chłopakami. Tak, że wkrótce wszystkich prześcignął” (s. 127). Oprócz doskonałej kondycji fizycznej postać z utworu Niziurskiego przewyższa rówieśników inteligencją, wiedzą, a nade wszystko dojrzałością. Potrafi wyjaśnić Michałowi - wiceadmirałowi Piratów - techniczną stronę działania rewolucyjnego silnika beztłokowego, określić skutki zastosowania go w przemyśle motoryzacyjnym. Wódz Kolonistów o wymownym nazwisku „Kszyk” (Kosiński, 2006, s. 131) patrzy na Tubylców z pozycji mądrzejszego, uświadomionego młodego aktywisty. Widzi w nich bandę szczeniaków, która zamiast angażować się w pożyteczne akcje, np. porządkowanie terenu Ogrodu, zajmuje się „beznadziejną, głupawą zabawą w Piratów" (s. 130).

Tak, teraz Andrzej obejmie kierownictwo ideologiczne. Dawno już marzył o ucywilizowaniu tutejszych dzikich, tubylczych plemion. Skończą się wojny, marnowanie czasu i poszukiwanie skarbów. Będą robić pożyteczne akcje, a bawić się w modelarni i na boisku. O, już Andrzej potrafi wziąć się za nich. Tym bardziej, że przecież wszyscy są harcerzami, a Andrzej zostanie chyba w tym roku przybocznym i będzie nosił zielony sznur. Doktor Otrębus dał mu do zrozumienia. [...] I wtedy zorganizuje tych chłopców w nowoczesną paczkę. Ale pomyślał, że to już marzycielstwo, i wzdrygnął się. Powinien być człowiekiem czynu i planować, a nie marzyć. Planować zaś można tylko z ołówkiem w ręku: tak mówi ojciec i doktor Otrębus. Z ołówkiem, a nie z gwizdkiem. Bo Andrzej ma właśnie w ręku gwizdek.

Dodać trzeba, że ten wzorowy uczeń przejął schematy myślenia oraz nowomowę od wspomnianego już Gwidona Otrębusa, którego podziwia, nazywając w myślach „człowiekiem nowoczesnym”, „człowiekiem jutra”. Zresztą socjalistyczną frazeologią posługuje się także sympatyczny łobuziak Zenon - admirał Piratów, przeciwieństwo Kszyka. Pytany, na co przeznaczą skarb Szwajsa, odpowiada bez wahania, że część oddadzą „na największe Cele Ideologiczne i Międzynarodowe", m.in. walczącym Murzynom i Fidelowi Castro (s. 152).

Koncepcja postaci wodza Kolonistów z jednej strony niewątpliwie nawiązuje do bohatera pozytywnego, ukształtowanego wedle wytycznych pedagogiki socjalistycznej, jeśli wziąć pod uwagę schematyzm i ilustracyjną funkcję. Z drugiej jednak strony obydwie sylwetki - młodziutkiego aktywisty oraz jego mentora Niziurski jawnie przerysował, dystansując się od nich albo raczej ośmieszając ich agitacyjną żarliwość i zadęcie oraz gorliwość w realizowaniu „szczytnych" celów.

Krytycy twórczości autora Awantury w Niekłaju zwracają uwagę na jego umiejętność zręcznego wykpiwania wszelakich mechanizmów peerelowskiej rze-

${ }^{5}$ Można tu mówić o tendencyjnej antroponimii, odwołującej się etymologicznie do bojowych nastrojów, jakie próbowano wywoływać wśród młodzieży w czasach stalinowskich. 
czywistości za pomocą różnych odmian komizmu, godzenia pryncypialności z ironią, z czym mamy do czynienia szczególnie w opisach dziecięcych zabaw. Antoni Smuszkiewicz, puentując zabawy Niziurskiego z komunistyczną frazeologią, komentował:

Satyryczne ujęcia rzeczywistości współczesnej, a zwłaszcza błyskotliwe i niespójne zestawienia wyrazów i zjawisk, które raczej ze sobą nie sąsiadują, zapewne oślepiły niejednego cenzora tak, iż nie zauważył (a może nie chciał zauważyć), jak autor znakomicie kpi sobie z języka propagandy i wynaturzeń realnego socjalizmu.

Smuszkiewicz, 2013, s. 285

\section{Uwagi końcowe}

Obraz dziecięcych gier i zabaw w Awanturze w Niekłaju obciąża dziedzictwo realnego socjalizmu. Bohaterowie nieświadomie przejmują hierarchię wartości, przeistaczają się z niesfornych łobuziaków w „bojowników słusznej sprawy", czego symbolicznym wyrazem będzie włożenie harcerskiego munduru. W drugiej z rozważanych powieści Niziurski broni prawa młodych do sztubackiej, „czystej” zabawy. Wszelkie draki Matusów i Blokerów nawiązują do utrwalonych w kulturze „paidialnych” i „ludycznych” form ekspresji. Autor Siódmego wtajemniczenia przekonująco odtwarza mechanizm tworzenia fantazmatów dzieciństwa - marzenia, by zmaterializowała się „męska przygoda” — wielka zgrywa w gronie wtajemniczonych, w bandzie Wspaniałych, którzy bez wahania spenetrują miejsca zakazane, podejrzane strychy, piwnice, stare browary. Fantazja o byciu detektywem, rozwiązującym nawet najbardziej skomplikowane zagadki kryminalne, zanim do akcji wkroczą dorośli i organy ścigania, mocno wryła się w pamięć pisarza i publicysty Michała Olszewskiego, który „wychował się" na tej prozie:

O uczestnictwie w świecie Niziurskiego marzyłem, czytając z latarką pod kołdrą Awantury kosmiczne, Naprzód! Wspaniali czy Adelo, zrozum mnie. Planowaliśmy przygody jak z jego książek, zakładając za garażami obok szkoły niezwykle tajne sprzysiężenie. Mieliśmy poważny zeszyt w kratkę, pseudonimy i zestaw szyfrów [...]. Mieliśmy dzidy, lance i piki złożone w pewnym miejscu. Szukaliśmy tajemnic na podwórku straży pożarnej (stara lodówka przy płocie z butelkami po piwie wewnątrz), na obrzeżach wielkiego osiedla, na torach i koło ogródków działkowych, w pejzażu małego miasta podobnego do tych, które opisywał Nizurski w większości książek. Jeszcze nie do końca świadomi, że nie każdy ojciec nadaje się na postać mityczną, a uczynni milicjanci biją czasem na śmierć. 
Nostalgię za dziecięcą ekscytacją przełamuje ironiczna uwaga o ówczesnej niewinności i niewiedzy, która chroniła utopię „bezgrzesznych lat”. Zmiana spojrzenia, krytycyzm wobec prozy Niziurskiego były nieuchronne, co nie zmienia faktu, że obcowanie z jego książkami było, według Olszewskiego, ważnym doświadczeniem generacyjnym. Podkreślił to, puentując dorobek pisarza Lermontowską formułą „bohater naszych czasów”. Kogo Olszewski miał na myśli? Samego autora Sposobu na Alcybiadesa czy może młodocianego detektywa Maćka Pirydiona, szkolnego cwaniaka Ciamciarę, czy jednak wiecznego pechowca Marka Piegusa? Autor artykułu pozostawia to pytanie otwartym.

\section{Literatura}

Baluch A., 1992, Archetypy literatury dziecięcej, Kraków.

Białek J.Z., 1996, Twórczość Edmunda Niziurskiego na tle literatury powojennej dla dzieci i młodzieży, w: Pacławski J., Kątny M., red., Edmund Niziurski. Materiały z sesji $w 70$. rocznice urodzin, Kielce.

Caillois R., 1973, Ludzie a gry i zabawy, w: tegoż, Żywioł i ład, Osęka A., wyb., Tatarkiewicz A., przeł., Porębski M., przedm., Warszawa.

Cieślikowski J., 1985, Wielka zabawa. Folklor dziecięcy - wyobraźnia dziecka - wiersze dla dzieci, Wrocław.

Eliade M., 1997, Inicjacja, obrzędy, stowarzyszenia tajemne, Kocjan K., przeł., Kraków.

Janion M., Żmigrodzka M., 2001, Romantyzm i historia, Gdańsk.

Kosiński K., 2006, Oficjalne i prywatne życie młodzieży w czasach PRL, Warszawa.

Kotliński A., 1999, Pluć i łapać. O PRL-owskiej prozie dla dzieci i młodzieży, w: Czapliński P., Śliwiński P., red., Nuda w kulturze, Poznań 1999.

Niewczas A., 1978, Polska wspótczesna powieść przygodowa. Próba konstrukcji matrycy fabularnej, „Roczniki Humanistyczne”, z. 1.

Niziurski E., 1977, Adelo, zrozum mnie!, Warszawa.

Niziurski E., 1975, Awantura w Niekłaju, Warszawa.

Niziurski E., 1978, Awantury kosmiczne, Katowice.

Niziurski E., 1969, Ksiegga urwisów, Warszawa.

Niziurski E., 1977, Naprzód, Wspaniali!, Warszawa.

Niziurski E., 1972, Siódme wtajemniczenie, Katowice.

Nowak P., Ryszkiewicz M., 2006, Socrealizm w literaturze dla dzieci i młodzieży. Retoryczna analiza powieści oraz czasopism, w: Stępnik K., Piechota M., red., Socrealizm. Fabuly - komunikaty - ikony, Lublin 2006.

Olszewski M., 2007, Vivacubaroja: bohater naszych czasów, „Tygodnik Powszechny”, nr 35.

Skotnicka G., 1996, Przygoda w powieściach dla dzieci i młodzieży Edmunda Niziurskiego. Rodzaje, struktura, funkcje, w: Pacławski J., Kątny M., red., Edmund Niziurski. Materiały $z$ sesji w 70. rocznicę urodzin, Kielce 1996.

Smuszkiewicz A., 2013, W świecie przygody i humoru, czyli o twórczości Edmunda Niziurskiego, w: tegoż, Fantastyka i pajdologia. Studia i szkice, Poznań. 
Waksmund R., 2000, Od literatury dla dzieci do literatury dziecięcej (tematy - gatunki-konteksty), Wrocław.

Winter R., 2012, Nuda w kulturze rozrywki. Poradnik, Kasprzyk Z., przeł., Kraków.

\section{Źródło internetowe}

Słownikjęzyka polskiego PWN. [Dokument elektroniczny].http://sjp.pwn.pl/sjp/1.;2445871 [data dostępu: 1.01.2017].

Małgorzata Chrobak - pracuje w Instytucie Filologii Polskiej Uniwersytetu Pedagogicznego w Krakowie (obecnie na stanowisku adiunkta w Katedrze Literatury Polskiej XX wieku oraz Pracowni Literatury dla Dzieci i Młodzieży). Jej zainteresowania badawcze obejmują zagadnienia związane z polską i obcą prozą dla młodego czytelnika XX i XXI wieku, literaturą okresu PRL-u, nurtem inicjacyjnym, antropologią oraz topiką dziecka i dzieciństwa w kulturze XX wieku. Autorka monografii: Realizm magiczny w polskiej literaturze dla dzieci i młodzieży (Kraków 2010); współredaktorka tomów, m.in.: Kraków mityczny. Motywy, wątki, obrazy w literaturze dla dzieci i młodzieży (Kraków 2009); Noosfera literacka. Problemy wychowania i terapii poprzez literature dla dzieci (Rzeszów 2012); O tym, co Alicja odkryła. W kręgu badań nad toposem dzieciństwa i literatura dla dzieci i młodzieży (Kraków 2015); Światy dzieciństwa. Infantylizacje $w$ literaturze i kulturze (Kraków 2016), a także licznych artykułów w książkach zbiorowych z zakresu historii, teorii oraz kultury dla dzieci i młodzieży.

e-mail: chrobak.malgorzata18@gmail.com 